\title{
Spatial and temporal structure of the meroplankton community in a sub-Arctic shelf system
}

\author{
Marc J. Silberberger ${ }^{1, *}$, Paul E. Renaud ${ }^{2,3}$, Boris Espinasse $^{1}{ }^{1}$ Henning Reiss $^{1}$ \\ ${ }^{1}$ Faculty of Biosciences and Aquaculture, Nord University, 8049 Bodø, Norway \\ ${ }^{2}$ Akvaplan-niva, Fram Centre for Climate and the Environment, 9296 Tromsø, Norway \\ ${ }^{3}$ University Centre in Svalbard, 9171 Longyearbyen, Norway
}

\begin{abstract}
The early development of many benthic invertebrates involves planktonic larval stages enabling larvae to disperse over large distances and to utilize food from the productive upper water layers. Although many past studies have recognized the importance of this period in the benthic life cycle, knowledge of larval distribution in time and space remains limited, especially for high-latitude regions with pronounced seasonal variability in environmental conditions. Here, we present the first inventory of meroplankton over the continental shelf in the Lofoten-Vesterålen region, northern Norway, over a full annual cycle. Six stations were sampled during 8 sampling events between September 2013 and August 2014. We recorded a total of 65 taxa, a considerably higher diversity than reported in studies from more northern regions. We observed a distinct seasonal pattern with characteristic meroplankton communities defining the seasons: spring, summer, and winter. Abundance and diversity during winter was low, with higher values in spring, and maximum abundances for most taxa in summer. Meroplankton community patterns did not reflect weak environmental spatial structure. Particle tracking was used to identify source and settlement locations of spring and summer communities. Spring and summer communities originated from shore and shelf areas, respectively. Larvae were generally transported toward Andfjord and adjacent shelf regions, irrespective of season. This spatially restricted dispersal and larval settlement highlights the importance of the local benthic communities for the resilience of the ecosystem.
\end{abstract}

KEY WORDS: Planktonic larvae $\cdot$ Larval dispersal $\cdot$ Seasonality $\cdot$ Invertebrate larvae $\cdot$ Norwegian waters $\cdot$ Environmental factors $\cdot$ High latitude

\section{INTRODUCTION}

The majority of benthic invertebrates are sedentary during their adult life, therefore limiting their dispersal largely to their early life stages. Consequently, many species have planktonic larvae to enable local and regional dispersal of their offspring (Becker et al. 2007). The planktonic phase also provides access to food in the productive upper water column, reduces intra- and interspecific competition, avoids predation by abundant benthic omnivores, and reduces inbreeding (Pechenik 1999, Palumbi 2003). At the same time, pelagic larvae risk being carried away from favorable settlement locations by the prevailing currents and expose themselves to

${ }^{*}$ Corresponding author: marc.j.silberberger@nord.no high predation pressure in the plankton (Pechenik 1999).

Larval duration in the water column varies among species (hours to several weeks), but substantial intraspecific variation also occurs depending on water temperature and food availability (Thorson 1950, Hadfield \& Strathmann 1996, O'Connor et al. 2007). Furthermore, successful larval recruitment may hinge on the timing of spawning, and some species spawn in synchrony with phytoplankton blooms or increased spring temperatures (Crisp \& Spencer 1958, Highfield et al. 2010). Seasonal variation in hydrodynamics also interacts with the timing of larval release because encounter with a suitable benthic habitat ultimately influences larval success

(C) The authors 2016. Open Access under Creative Commons by Attribution Licence. Use, distribution and reproduction are unrestricted. Authors and original publication must be credited. 
(Metaxas 2001, Ayata et al. 2011). Although a substantial literature discusses reproductive strategies and larval nutrition in holoplankton (taxa spending their entire lives in the water column) (Varpe et al. 2009, Daase et al. 2013), the transferability of all of these conceptual models directly to studies of the pelagic developmental stage of benthic organisms (meroplankton) remains unclear.

Historically, aside from early studies indicating a decreasing importance of planktonic larvae for benthic reproduction with increasing latitude (Thorson 1950, Mileikovsky 1971), few studies have examined meroplankton in polar regions. Several recent studies have put this gap into perspective. Fetzer \& Arntz (2008) provided detailed estimates on the relative importance of different developmental modes for the dominant benthic species in the Kara Sea, showing many species with benthic development (about 30\%) driven almost exclusively by the large number of peracarid crustaceans in the study area that lack pelagic development. Their analysis showed a predominance of pelagic development outside this group. Furthermore, recent studies of Arctic meroplankton have shown that planktonic larval stages of benthic organisms comprise a considerable fraction of the total zooplankton community (Clough et al. 1997), and may dominate during productive seasons in terms of abundance and biomass (Stübner et al. 2016). Furthermore, meroplankton diversity observed in Arctic and sub-Arctic regions points to the importance of a bentho-pelagic life cycle in these regions (Andersen 1984, Schlüter \& Rachor 2001) that can provide insight into adult distributions and potential range extensions for benthic species in the context of climate change (e.g. Renaud et al. 2015).

Distinct knowledge gaps about the spatio-temporal distribution of larvae remain. Kuklinski et al. (2013) and Stübner et al. (2016) investigated an Arctic meroplankton community over a 12 mo period, and detected a strong seasonal pattern with meroplankton present nearly year-round in a high Arctic fjord. Plankton community studies have provided limited additional information on the seasonality of Arctic and sub-Arctic meroplankton (Willis et al. 2006); however, these studies all investigated temporal patterns in enclosed fjord environments, with no studies specifically addressing open-shelf meroplankton seasonality. This lack of knowledge juxtaposes the importance of meroplankton dispersal and subsequent recruitment for the resilience of benthic ecosystems in response to natural and anthropogenic disturbances, including climate change (Kirby et al. 2008).
In this study, we present the first inventory of the meroplankton community at 6 stations in a subArctic shelf system over a 12 mo period from September 2013 to August 2014. The main objectives were to (1) describe the spatial and temporal distribution of meroplankton in relation to large-scale benthic habitats and water mass properties; and (2) to further evaluate the importance of environmental variables and the spatial and temporal characteristics of the sampling regime in structuring the meroplankton community. Furthermore, we used a particle-tracking approach to identify possible source and settlement locations of the meroplankton sampled in this study.

\section{MATERIALS AND METHODS}

\section{Study area}

Although our study location on the continental shelf off the coast of the Vesterålen Islands in northern Norway (Fig. 1) occurs north of the Arctic Circle, and therefore experiences pronounced seasonality in day length with periods of complete darkness (polar night) and permanent light (midnight sun), the strong influence of the North Atlantic Current results

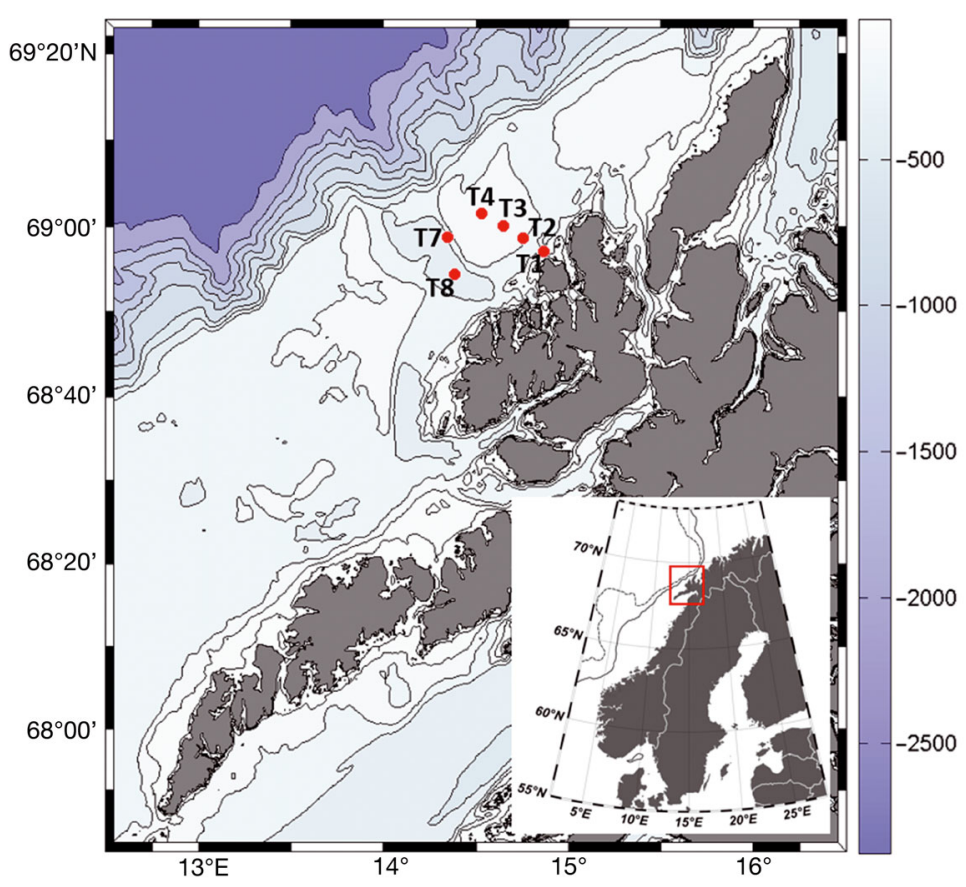

Fig. 1. Study area with bathymetry indicated by the color scale (unit: $\mathrm{m}$ ). Sampling stations are indicated by red points. Inset: location of the study area in Norway, indicated by a red rectangle 
in a permanently ice-free environment. Two major features comprise the narrow continental shelf in the area: shallow banks with hard substrate of bedrock and boulders contrast deep cross-shelf trenches with sandy or gravelly substrate (Buhl-Mortensen et al. 2012). Two northward-flowing currents characterize the regional hydrography. The low-salinity Norwegian Coastal Current flows over the shelf along the coast, whereas the warm and saline Norwegian Atlantic Current travels along the continental slope and frequently flushes onto the shelf (Bøe et al. 2009).

\section{Sampling and sample processing}

Plankton samples were collected at 6 stations (Fig. 1, Table 1) during 8 sampling events between September 2013 and August 2014 (see Table 2 for sampling dates). The 6 stations were selected to represent the major marine landscapes in the study area (Mortensen et al. 2009) and to cover most of the shelf width, with distance from shore between 1 and $20 \mathrm{~km}$ (Table 1). A WP2 closing net (opening $=0.25 \mathrm{~m}^{2}$, mesh size $=200 \mu \mathrm{m}$ ), equipped with a CTD profiler with fluorescence sensor (Saiv A/S, CTD/CSD model SD 204), sampled the complete water column at shallow stations (T1-T4, depth $<100 \mathrm{~m}$ ) in a single vertical tow. At deeper stations (T7 and T8, depth $>100 \mathrm{~m}$ ), we collected plankton from 2 depth intervals: estimated maximum mixed-layer depth (50-0 m) and deeper water (bottom-50 m). At each of these stations, we also collected a separate CTD profile of the entire water column. We chose a mesh size commonly used for sampling larger and relative mobile meroplankton, such as decapod zoea (e.g. Highfield et al. 2010, Koettker \& Lopes 2013). However, this sampling gear may under-represent small larvae and early stages of some groups (e.g. Bivalvia). Samples were fixed in $4 \%$ buffered formaldehyde until further processing. Unfavorable weather conditions precluded sampling at station

Table 1. Geographic position, bottom depth, distance from shore, and marine landscape of the sampling stations

\begin{tabular}{|lccccc|}
\hline Station & $\begin{array}{c}\text { Longitude } \\
\left({ }^{\circ} \mathrm{E}\right)\end{array}$ & $\begin{array}{c}\text { Latitude } \\
\left({ }^{\circ} \mathrm{N}\right)\end{array}$ & $\begin{array}{c}\text { Depth } \\
(\mathrm{m})\end{array}$ & $\begin{array}{c}\text { Distance from } \\
\text { shore }(\mathrm{km})\end{array}$ & $\begin{array}{c}\text { Marine } \\
\text { landscape }\end{array}$ \\
\hline T1 & $14^{\circ} 51.9846^{\prime}$ & $68^{\circ} 57.0048^{\prime}$ & 40 & 1.389 & Fjord and coast \\
T2 & $14^{\circ} 45.2226^{\prime}$ & $68^{\circ} 58.6056^{\prime}$ & 75 & 6.360 & Bank \\
T3 & $14^{\circ} 38.7630^{\prime}$ & $69^{\circ} 00.0378^{\prime}$ & 75 & 10.583 & Bank \\
T4 & $14^{\circ} 31.7700^{\prime}$ & $69^{\circ} 01.5690^{\prime}$ & 80 & 16.201 & Bank \\
T7 & $14^{\circ} 20.6526^{\prime}$ & $68^{\circ} 58.7430^{\prime}$ & 215 & 18.669 & Shelf trench \\
T8 & $14^{\circ} 23.1450^{\prime}$ & $68^{\circ} 54.4638^{\prime}$ & 260 & 11.927 & Shelf trench \\
\hline
\end{tabular}

T8 on 10 September 2013 and a malfunctioning CTD resulted in no CTD data at station T7 on 1 May 2014.

CTD data (practical salinity, temperature, and pressure) were transformed following recommendations of the Intergovernmental Oceanographic Commission (IOC et al. 2010). All seawater properties were calculated using the Gibbs SeaWater package in R (Kelley et al. 2015). Absolute salinity $\left(S_{\mathrm{A}}\right)$, conservative temperature $(\Theta)$, fluorescence $(F)$, and the potential density anomaly referenced to 0 dbar $\left(\sigma_{\theta}\right)$ were then averaged for $2 \mathrm{~m}$ depth bins, starting at $1 \mathrm{~m}$ depth, to smooth the data. The mixed-layer depth was defined as the depth where the difference between $\sigma_{\theta}$ and the surface value was $0.03 \mathrm{~kg} \mathrm{~m}^{-3}$ (Talley et al. 2011).

Samples were split in the laboratory consecutively with a Motoda plankton splitter until a minimum count of 400 individuals or one-quarter of the total sample was processed. Meroplankton were identified to the lowest feasible taxonomic level. We standardized the original count data for the analyzed fraction to individuals per $\mathrm{m}^{2}$ surface area (ind. $\mathrm{m}^{-2}$ ) and integrated the 2 depth intervals for stations $\mathrm{T} 7$ and $\mathrm{T} 8$ to represent the whole water column.

\section{Statistical analysis}

All statistical analyses were performed in $\mathrm{R}$, version 3.2.0 (R Core Team 2015).

We calculated the number of taxa, total abundance, the Shannon index ( $\left.H_{\text {log e }}^{\prime}\right)$ (Shannon 1948), and Pielou's evenness $\left(J^{\prime}\right)$ (Pielou 1977) for every sample to compare diversity between samples.

Although we report only results from log-transformed data unless otherwise stated, we ran multivariate analyses with 3 different transformations to explore all quantitative aspects of the data: (1) no transformation (raw), (2) natural logarithm (log), and (3) presence and absence data.

A triangular dissimilarity matrix was created using Bray-Curtis dissimilarities (Bray \& Curtis 1957). Global nonmetric multidimensional scaling (GNMDS) ordinations were run with 100 restarts from random starting positions. The maximum number of iterations was set to 500 and the convergence criterion to $10^{-7}$. Rescaling of the axes in half-change units was applied (Gauch 1973). Similarity profile analysis (SIMPROF) (average link- 
age; $\mathrm{p}<0.01)$ verified patterns observed in the GNMDS ordinations. A species contribution analysis, as described by van Son \& Halvorsen (2014), was performed to identify taxa contributing to observed differences in season patterns.

For variation partitioning, we created 4 matrices with explanatory variables. The first matrix contained 9 spatial variables: $x, y, x^{2}, x y, y^{2}, x^{3}, x^{2} y, x y^{2}$, and $y^{3}$. Universal Transverse Mercator (UTM) grid coordinates $x$ and $y$ of the sampling stations (5 digits for each coordinate) were used as the principal geographic information. Following Legendre (1990) and Anderson \& Cribble (1998), we included all terms of a cubic trend surface regression in the matrix to allow more complex structures such as patches. The second matrix contained 11 environmental variables: depth, marine landscape, distance from shore (all constant over the study period), surface and bottom temperature, surface and bottom salinity, mean and maximum fluorescence, depth of maximum fluorescence, and mixed-layer depth. The marine landscape for each station was assigned following Mortensen et al. (2009). To determine the distance from shore of each sampling station, we used the gDistance function in the rgeos package (Bivand et al. 2015) together with the National Geospatial-Intelligence Agency's Prototype Global Shoreline Data (NGA 2009). All other parameters were based on individual CTD casts. Bottom CTD values were averages of the deepest $2 \mathrm{~m}$ bin, ending approximately $5 \mathrm{~m}$ above bottom. We included depth, marine landscape, and distance from shore in the matrix of environmental variables, even though they are not typical environmental variables in plankton research, because of their importance for local benthic communities. These measures also provide surrogates for other environmental variables not measured in our study (e.g. inputs of fresh water and terrigenous material decrease with distance from shore). The other 2 matrices contained a single temporal variable each: the sampling date expressed as day of year and sampling season, defined according to season-groups identified in the GNMDS ordinations. Two temporal matrices were used, since the season-groups were defined a posteriori. Including these 2 temporal sets of explanatory matrices allowed us to quantify additional variation in the meroplankton explained by knowledge of local seasons.

Each of the 4 matrices was subjected to forward selection using a series of constrained and partially constrained canonical correspondence analyses (CCA) followed by unrestricted permutation tests (999 permutations, $p<0.01$ ). In each selection round, we selected the variable with the highest significant explanatory power for use as a conditioning variable for all the following selection rounds. Variables were selected until none added significantly to the explanation of the variation in the meroplankton data. In this way, we avoided artificially inflating the explained variation by including co-variables in the analysis.

Given the lack of explanatory power in any spatial variables (see 'Results'), we performed a variation partitioning through constrained and partially constrained CCA with all possible combinations of the 2 temporal and the environmental datasets. Variation explained by environmental variables only (E), sampling date only (D), season only (S), environment and season combined (ES), environment and sampling date combined (ED), sampling date and season combined (DS), and a combination of all 3 (EDS) were determined following Anderson \& Cribble (1998) for variation partitioning on 3 sets of explanatory variables. To visualize the results of the variation partitioning, we generated a Euler diagram with the eulerAPE software (Micallef \& Rodgers 2014).

We tested for autocorrelation between the meroplankton community, the environmental dataset, and space using Mantel and partial Mantel tests (Legendre \& Legendre 1998), removing the factor variable marine landscape from the environmental variables.

All multivariate analyses used the vegan package version 2.3-0 (Oksanen et al. 2015).

\section{Particle tracking}

For tracking of larval dispersal pathways, we simulated velocity fields using the ocean modeling system NorKyst-800 (Albretsen et al. 2011). NorKyst-800 is based on the public domain Regional Ocean Modeling System, a 3D free-surface, hydrostatic, primitive equation ocean model using terrain-following s-coordinates in the vertical (Shchepetkin \& McWilliams 2005, Haidvogel et al. 2008). In summary, we combined bathymetric data (50 $\mathrm{m}$ resolution) from the Norwegian Mapping Authority Hydrographic Service with lateral boundary conditions from the Norwegian Meteorological Institute (MET)'s Nordic4km, atmospheric forcing from MET's weather forecast model HIRLAM10km, tidal forces from a global inverse barotropic model of ocean tides (TPXO7.2), and Norwegian river discharge modeled by the Norwegian Water Resources and Energy Directorate. Recent studies have used the NorKyst-800 model 
with success, showing relatively good agreement with field data (e.g. Myksvoll et al. 2014, Skarðhamar et al. 2015). The model domain covered the whole Norwegian Sea from $55.8^{\circ}$ to $73.8^{\circ} \mathrm{N}$ and $0.5^{\circ} \mathrm{W}$ to $34.8^{\circ} \mathrm{E}$, with $820 \times 2420$ grid cells in the horizontal, each $800 \times 800 \mathrm{~m}$ in size.

Larval dispersal and origin were simulated using the individual-based model ICHTYOP (Lett et al. 2008), by tracking particles released inside an area around station T3. Hourly velocity fields from NorKyst-800 were used to simulate Lagrangian particle transport. A patch of 1000 particles was uniformly distributed in a $10 \mathrm{~km}$ diameter circular area between $20 \mathrm{~m}$ depth and the surface, and passively advected for $28 \mathrm{~d}$, both forward and backward in time. Our simulation allowed transport of particles throughout the water column. We chose a duration of $28 \mathrm{~d}$ because the planktonic period for the majority of taxa in the study area (see Supplement 1 at www.int-res.com/articles/suppl/m555p079_supp.pdf) ranges from 3-6 wk (Mortensen 1927, Johannesson 1988, Shanks et al. 2003, Conway 2015). To account for the presence of different stages of larvae, we acquired weekly results in the simulations. Our simulation contrasted 2 periods during which typical spring (1 May 2014) or summer (22 July 2014) meroplankton communities were present.

\section{RESULTS}

\section{Oceanography}

Surface temperature and salinity in the study area varied seasonally, with high temperatures during summer and low salinity in late summer and autumn (Fig. 2). Surface temperature varied little spatially at any sampling date. Surface salinity, however, differed among sampling stations, but with no clear reoccurring pattern. Pronounced surface salinity outliers occurred, particularly at the deep stations T7 and T8, potentially indicating short-lived local high and low salinity patches over the shelf trench. Bottom temperature also showed distinct seasonality, with the highest temperatures in late summer and autumn. The strongest seasonality at the shallower stations (T1-T4; temperature range: $4.5-11.7^{\circ} \mathrm{C}$ ) contrasted the weaker seasonality at the deeper stations ( $\mathrm{T} 7$ and $\mathrm{T} 8$; temperature range: $6.1-8.0^{\circ} \mathrm{C}$ ). In contrast to the other variables, bottom salinity varied spatially but not seasonally. Salinities above 35 characterized bottom waters at stations T7 and T8 throughout the year, with a single outlier at station
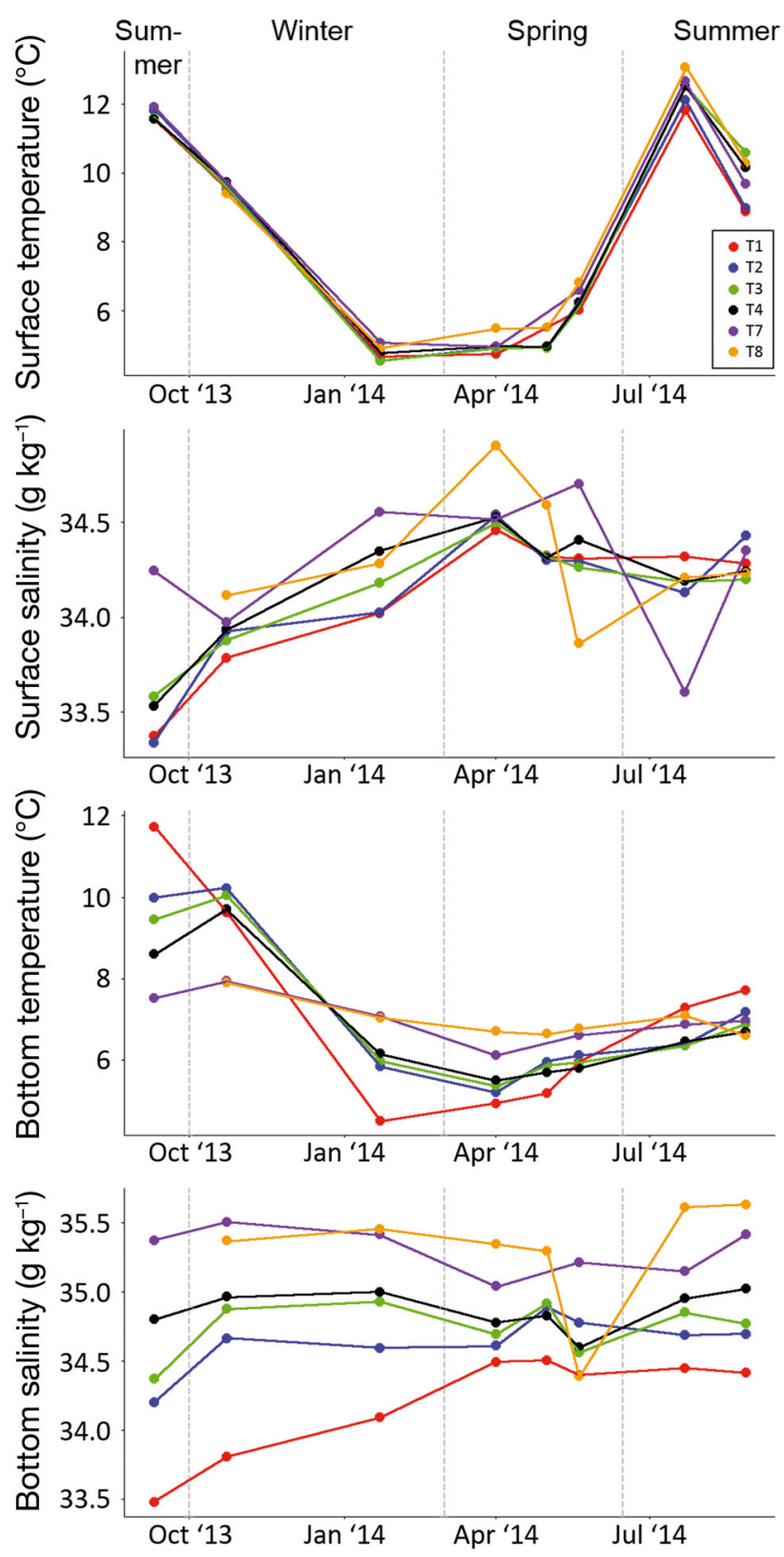

Fig. 2. Surface and bottom temperature and salinity at each sampling station over the whole study period. Sampling stations are indicated by different colors; identified seasons are separated by vertical lines

T8 in May. This high salinity over 35 assigns this bottom water to a Norwegian Atlantic Current origin. Salinities below 35 throughout the year, typical for the Norwegian Coastal Current, characterized bottom water at the shallower stations. The mixed-layer depth in the study area indicated deeper mixing from October to early May and a more stable surface layer in late spring and throughout the summer. The fluorescence values indicate mid-May and August phytoplankton blooms. 


\section{Meroplankton community}

All samples analyzed contained planktonic larvae of benthic invertebrates, which we assigned to 65 different taxa in 11 phyla (see Supplement 1 at www.intres.com/articles/suppl/m555p079_supp. pdf). On average, samples contained 14041 ind. $\mathrm{m}^{-2}$ (range: 32-79 392 ind. $\mathrm{m}^{-2}$ ) in 15 different taxa (range: 1-35). Mean number of taxa, abundance, $H^{\prime}$ log e and $J^{\prime}$ varied seasonally, with low abundances and diversity in October and January and a peak in the summer months (Table 2). Spatial variation was low relative to seasonal variation. Abundances were highest at stations closest to shore (T1 and T2). Lower average numbers of taxa occurred at the stations farthest offshore (T4 and T7). $H^{\prime}{ }_{\text {log e }}$ and $J^{\prime}$ did not vary spatially.

The 5 most abundant taxa in this study were the polychaete family Amphinomidae (mean abundance: 3724 ind. $\mathrm{m}^{-2}$ ), the bryozoan Membranipora membranacea (2114 ind. $\mathrm{m}^{-2}$ ), the barnacle Verruca stroemia (1642 ind $\mathrm{m}^{-2}$ ), echinoderms of the class Ophiuroidea (1048 ind. $\mathrm{m}^{-2}$ ), and gastropods assigned to the group Littorinimorpha type (979 ind. $\mathrm{m}^{-2}$ ). These 5 taxa accounted for $67.7 \%$ of the total meroplankton abundance.

Table 2. Number of taxa, total abundance, Shannon index $\left(H^{\prime}{ }_{\log }\right.$ e $)$ and evenness $\left(J^{\prime}\right)$. Data shown are mean values \pm SD for each station and each sampling date

\begin{tabular}{|c|c|c|c|c|}
\hline & Taxa (n) & Abundance (ind. $\mathrm{m}^{-2}$ ) & $H^{\prime} \log \mathrm{e}$ & $J^{\prime}$ \\
\hline \multicolumn{5}{|l|}{ Station } \\
\hline $\mathrm{T} 1$ & $16.6 \pm 10.4$ & $20780 \pm 31310$ & $1.63 \pm 0.48$ & $0.66 \pm 0.18$ \\
\hline $\mathrm{T} 2$ & $15.6 \pm 9.6$ & $19388 \pm 28079$ & $1.56 \pm 0.79$ & $0.62 \pm 0.16$ \\
\hline T3 & $17.0 \pm 8.6$ & $12408 \pm 15016$ & $1.70 \pm 0.56$ & $0.69 \pm 0.17$ \\
\hline $\mathrm{T} 4$ & $12.3 \pm 7.5$ & $12772 \pm 20718$ & $1.49 \pm 0.79$ & $0.73 \pm 0.14^{b}$ \\
\hline $\mathrm{T} 7$ & $13.5 \pm 7.7$ & $9690 \pm 15307$ & $1.64 \pm 0.37$ & $0.72 \pm 0.17$ \\
\hline $\mathrm{T}^{\mathrm{a}}$ & $15.6 \pm 7.2$ & $8491 \pm 9896$ & $1.58 \pm 0.42$ & $0.63 \pm 0.18$ \\
\hline \multicolumn{5}{|l|}{ Date } \\
\hline $01.09 .2013^{\mathrm{a}}$ & $23.0 \pm 9.4$ & $29395 \pm 34898$ & $2.19 \pm 0.12$ & $0.73 \pm 0.13$ \\
\hline 23.10 .2013 & $5.2 \pm 3.1$ & $403 \pm 201$ & $0.95 \pm 0.68$ & $0.63 \pm 0.20^{\mathrm{b}}$ \\
\hline 22.01 .2014 & $2.7 \pm 0.8$ & $72 \pm 30$ & $0.88 \pm 0.29$ & $0.93 \pm 0.11$ \\
\hline 01.04 .2014 & $10.5 \pm 2.5$ & $3029 \pm 1801$ & $1.37 \pm 0.41$ & $0.59 \pm 0.18$ \\
\hline 01.05 .2014 & $19.5 \pm 3.0$ & $9373 \pm 2740$ & $2.02 \pm 0.08$ & $0.69 \pm 0.05$ \\
\hline 20.05 .2014 & $20.8 \pm 3.4$ & $11677 \pm 3822$ & $1.93 \pm 0.22$ & $0.64 \pm 0.08$ \\
\hline 22.07 .2014 & $19.8 \pm 2.5$ & $52869 \pm 16993$ & $1.69 \pm 0.19$ & $0.57 \pm 0.08$ \\
\hline 27.08 .2014 & $20.5 \pm 2.6$ & $8037 \pm 4953$ & $1.86 \pm 0.38$ & $0.62 \pm 0.14$ \\
\hline
\end{tabular}

GNMDS.log

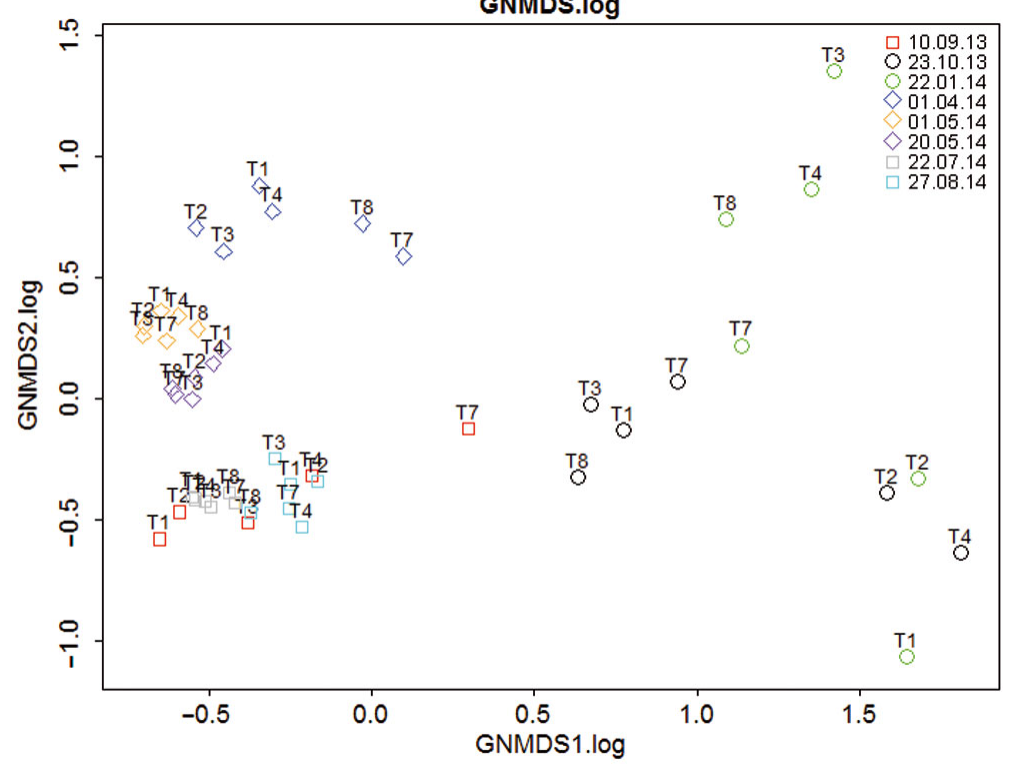

Fig. 3. Global nonmetric multidimensional scaling (GNMDS) results of logarithmic (log)-transformed meroplankton data. Sampling dates are indicated by different colors; labels are station numbers; symbols show season cluster according to similarity profile analysis: circles $=$ winter; diamonds = spring; squares $=$ summer

Multivariate community structure exhibited 3 distinct seasons (winter: 23 October 2013; 22 January 2014; spring: 1 April 2014; 1 May 2014; 20 May 2014; summer: 22 July 2014; 27 August 2014, 10 September 2013) in the GNMDS ordinations of the log-transformed data (Fig. 3), presence and absence data, and untransformed data. The SIMPROF analysis (not presented) supported this pattern, preserving these 3 season groups irrespective of transformations. The GNMDS ordinations also separated spring samples, where the sampling dates arranged chronologically, indicating a gradual development of the community towards the summer.

The GNMDS ordination revealed a spatial pattern in late summer (September) and a very weak pattern in early spring (April) only. In both months, samples from stations T7 and T8 were more similar to winter samples than all other spring and summer samples. In September, station T1 had the highest abundance and highest diversity of all samples (79392 ind. $\mathrm{m}^{-2}$; 35 taxa). Abundance decreased substantially with distance from shore 
(T4: 4016 ind. $\mathrm{m}^{-2} ; 18$ taxa) and even more to the deep trough (T7: 400 ind. $\mathrm{m}^{-2} ; 11$ taxa). In April, we observed a difference in abundance between deep (T7 and T8: 1064 ind. $\mathrm{m}^{-2}$ ) and shallow stations (T1-T4: 4012 ind. $\mathrm{m}^{-2}$ ). In addition, we observed spatial patterns for some taxa. Balanus balanus and Semibalanus balanoides occurred almost exclusively at shallow stations, whereas most individuals of Munida spp. occurred at deep stations. In contrast, Amphinomidae were equally distributed throughout the study area during their peak abundance in July, but were only present in samples from the deep stations on 20 May.

Seventeen taxa contributed to at least $5 \%$ of the difference between at least one season pair for at least one transformation (Table 3). All 17 taxa were virtually absent from the winter samples (Fig. 4). Accordingly, the taxa with the highest spring and summer abundances contributed most to separating winter samples from those from other seasons. S. balanoides was the taxon that reached its annual maximum abundance earliest (in April), followed by $B$. balanus, Spionidae, and Ophiuroidea in early May. These 4 taxa were representative of the spring meroplankton community and disappeared almost completely before the summer. The remaining taxa were abundant during the summer, and of these, only bivalves with Mya type larvae were equally high in abundance in spring and summer.

Most taxa appeared suddenly in the plankton and disappeared again after a short abundance peak. In contrast, the 2 bryozoans ( $M$. membranacea and Electra pilosa) occurred in high numbers from early May until September, increasing gradually over the season.

Although many taxa contributed to spring and summer differences, the dominant barnacle separated these seasons most clearly. Though present in all samples during the spring, $S$. balanoides and $B$. balanus effectively disappeared during the summer. In contrast, another barnacle, $V$. stroemia, occurred in very high abundances in all samples during summer, following low presence during spring. Furthermore, the ratio of $S$. balanoides to $B$. balanus changed from early spring to mid- and late spring, contributing to intraseasonal differences.

\section{Variables structuring the meroplankton community}

Forward-selection CCA showed that variables from the environmental and both temporal datasets explained significant variation in the meroplankton data, whereas spatial variables did not (see Supplement 2 at www.int-res.com/articles/suppl/m555p079 _supp.pdf). Therefore, we applied the variation partitioning method only for the 3 datasets with significant explanatory variables. After forward selection, the datasets included the following variables: environmental data (surface temperature, bottom tem-

Table 3. Results of the species contribution analysis for spring, summer, and winter for presence and absence (Qual.), logarithmic (Log.), and untransformed (Raw) meroplankton data. The average contribution of a taxon is $1.54 \%(=100 \% / 65$ taxa). Taxa contributing over $5 \%$ to the difference between a cluster pair for one transformation are shown. Contributions over $5 \%$ given in bold and contributions over $10 \%$ are given in bold italic. Values are rounded to 2 decimals

\begin{tabular}{|c|c|c|c|c|c|c|c|c|c|}
\hline \multirow[t]{2}{*}{ Taxa } & \multicolumn{3}{|c|}{ Spring vs. summer } & \multicolumn{3}{|c|}{ Spring vs. winter } & \multicolumn{3}{|c|}{ Summer vs. winter } \\
\hline & Qual. & Log. & Raw & Qual. & Log. & Raw & Qual. & Log. & Raw \\
\hline Galathea spp. & 0.03 & 0.03 & 0.01 & 0.03 & 0.02 & 0.00 & 0.05 & 0.05 & 0.01 \\
\hline Verruca stroemia & 0.01 & 0.04 & 0.14 & 0.05 & 0.05 & 0.02 & 0.05 & 0.08 & 0.15 \\
\hline Balanus balanus & 0.05 & 0.06 & 0.03 & 0.07 & 0.08 & 0.12 & 0.01 & 0.01 & 0.00 \\
\hline Semibalanus balanoides & 0.06 & 0.06 & 0.03 & 0.07 & 0.08 & 0.09 & 0.00 & 0.00 & 0.00 \\
\hline Membranipora membranacea & 0.01 & 0.03 & 0.12 & 0.02 & 0.04 & 0.12 & 0.03 & 0.06 & 0.16 \\
\hline Electra pilosa & 0.01 & 0.02 & 0.03 & 0.06 & 0.07 & 0.09 & 0.05 & 0.07 & 0.06 \\
\hline Amphinomidae & 0.05 & 0.05 & 0.32 & 0.01 & 0.02 & 0.04 & 0.05 & 0.06 & 0.33 \\
\hline Chaetopteridae & 0.06 & 0.05 & 0.02 & 0.00 & 0.00 & 0.00 & 0.05 & 0.05 & 0.02 \\
\hline Spionidae & 0.02 & 0.02 & 0.00 & 0.06 & 0.06 & 0.02 & 0.04 & 0.03 & 0.00 \\
\hline Hiatella type & 0.05 & 0.06 & 0.03 & 0.01 & 0.01 & 0.00 & 0.04 & 0.05 & 0.03 \\
\hline Mya type & 0.04 & 0.04 & 0.01 & 0.02 & 0.03 & 0.07 & 0.05 & 0.06 & 0.03 \\
\hline Mytilidae type & 0.06 & 0.06 & 0.02 & 0.01 & 0.00 & 0.00 & 0.06 & 0.06 & 0.02 \\
\hline Anomiidae type & 0.05 & 0.04 & 0.01 & 0.00 & 0.00 & 0.00 & 0.05 & 0.04 & 0.01 \\
\hline Littorinimorpha type & 0.01 & 0.03 & 0.07 & 0.01 & 0.03 & 0.03 & 0.02 & 0.05 & 0.08 \\
\hline Nudibranchia & 0.02 & 0.04 & 0.07 & 0.01 & 0.02 & 0.01 & 0.01 & 0.02 & 0.07 \\
\hline Ophiuroidea & 0.00 & 0.02 & 0.06 & 0.06 & 0.09 & 0.28 & 0.05 & 0.05 & 0.02 \\
\hline Echinoidea & 0.02 & 0.02 & 0.00 & 0.07 & 0.07 & 0.04 & 0.04 & 0.04 & 0.01 \\
\hline
\end{tabular}



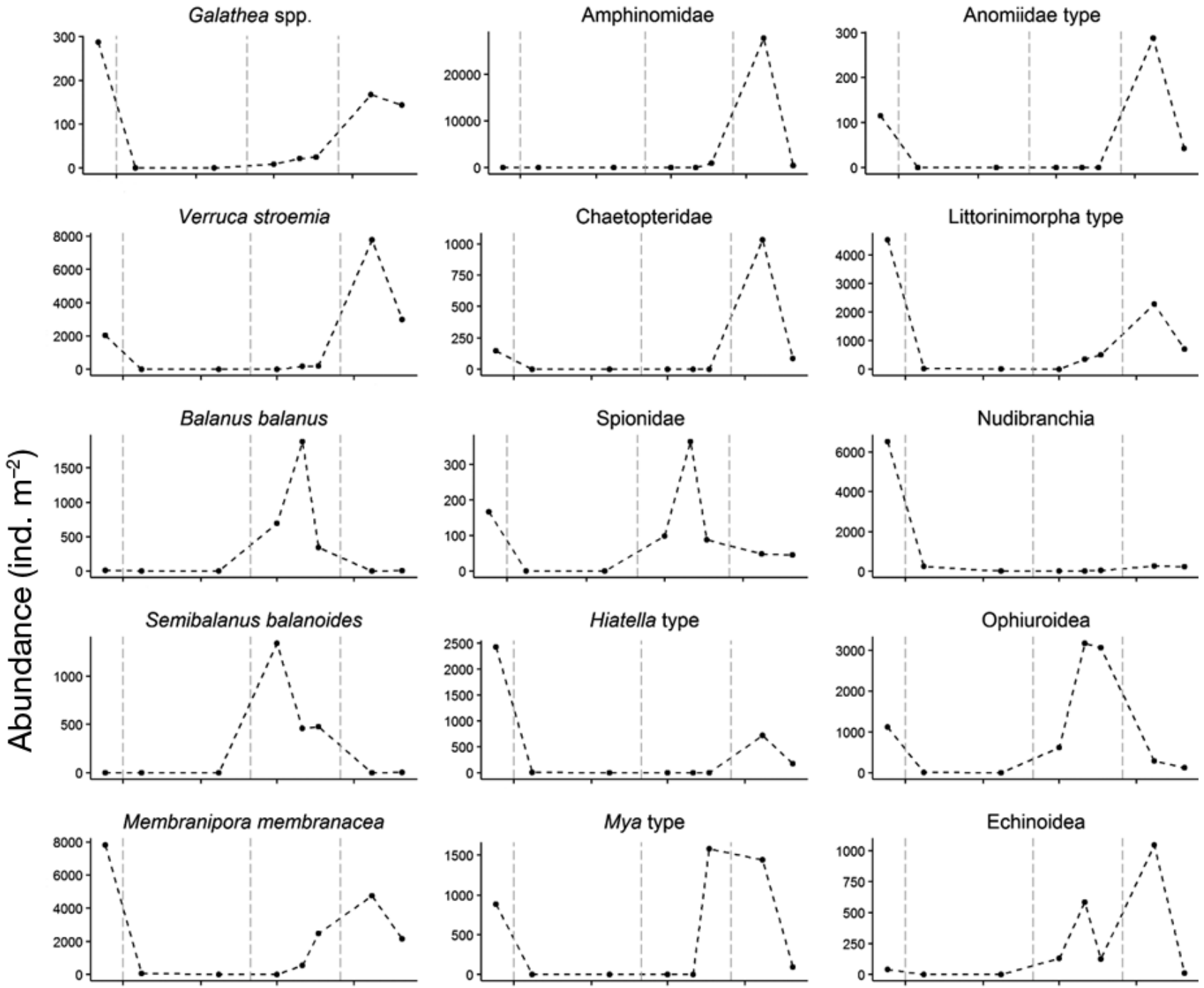

Mya type

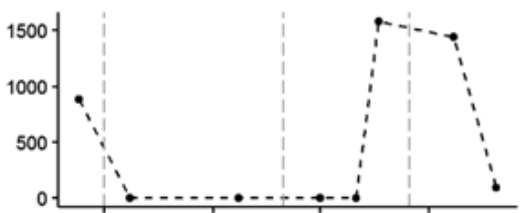

Echinoidea
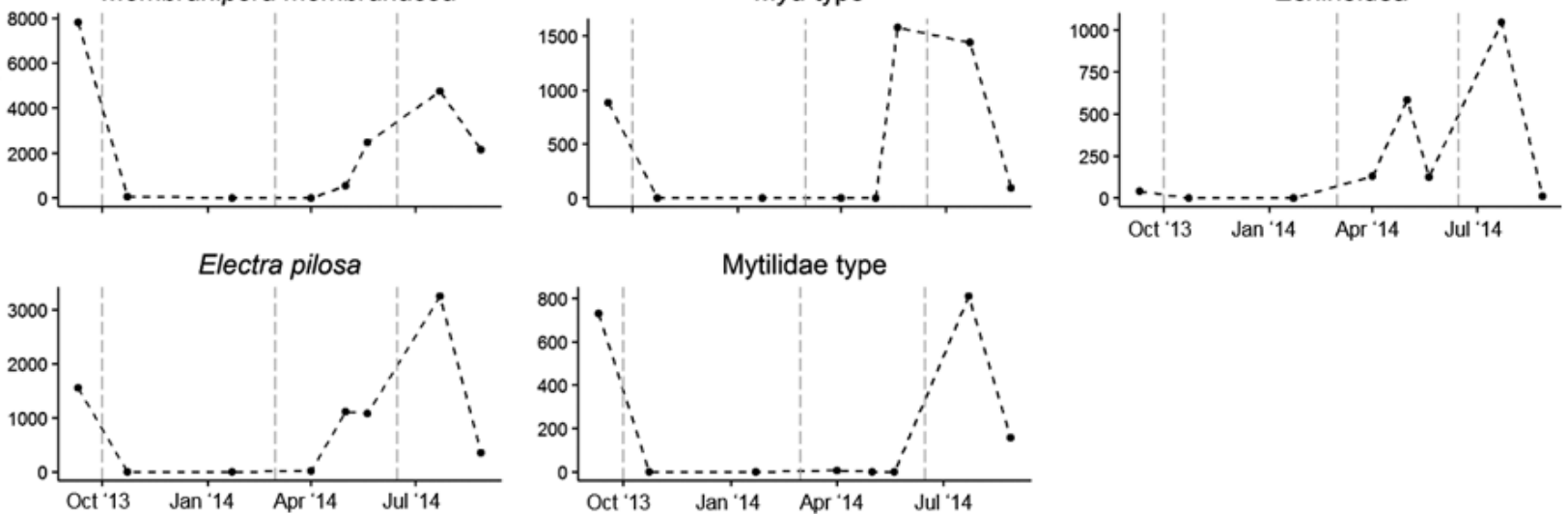

Fig. 4. Average abundances (ind. $\mathrm{m}^{-2}$ ) of the taxa contributing over $5 \%$ to the separation of 2 season clusters according to species contribution analysis results. Identified seasons are separated by vertical lines

perature, fluorescence maximum, bottom salinity), temporal 1 (season), and temporal 2 (sampling date). In total, these variables explained $35.5 \%$ of the total variance (TVE), leaving $64.5 \%$ unexplained. Variation explained exclusively by the environmental data accounted for the largest portion of the TVE, followed by variation explained by season alone and variation explained by all 3 sets of explanatory vari- ables (Fig. 5). The remaining 4 combinations of the datasets explained negligible variance.

Mantel and partial Mantel statistics (Table 4) support the results of the forward-selection CCA, indicating no significant correlations between the geographic distance matrix and the dissimilarity matrix of the log-transformed meroplankton data, but the environmental data correlated significantly with both. 


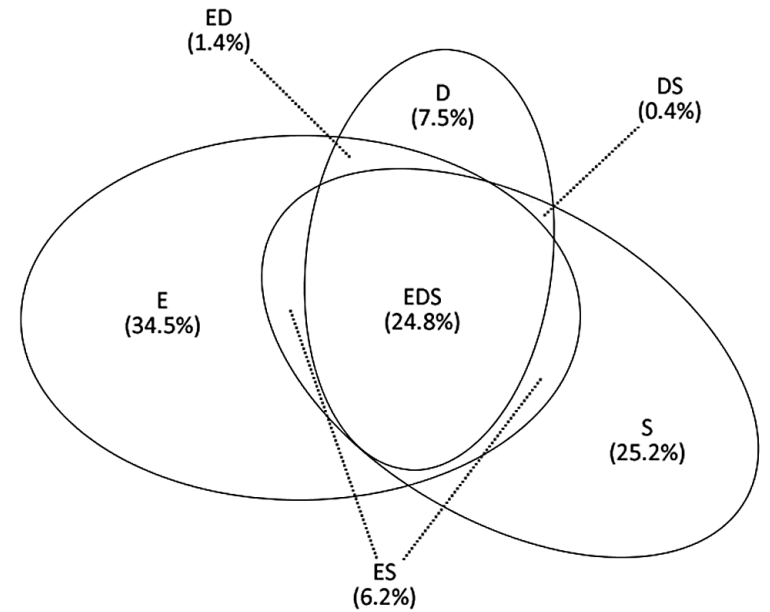

Fig. 5. Euler diagram showing the results of the variation partitioning for the logarithmic-transformed meroplankton data. The percentages indicate the relative contribution of each explanatory data set $(\mathrm{E}=$ environment; $\mathrm{D}=$ sampling date; $\mathrm{S}=$ season) and all combinations of them to the total variation explained $($ TVE $=35.5 \%)$

\section{Larval dispersal and origins}

The May model advected a fraction of the particles northward relatively quickly along the continental slope, with some reaching $70.5^{\circ} \mathrm{N}$ latitude within just 2 wk and $9.7 \%$ of particles advected north of $71^{\circ} \mathrm{N}$ after 4 wk (Fig. 6A). The July simulation advected comparatively few particles along the slope, transporting particles northeastward onto the shelf and closer to the coast; $5.1 \%$ of the particles moved over $20^{\circ} \mathrm{E}$ by the end of the simulation. In both May and July, a significant percentage of the particles ended up in Andfjord (41.9\% and 34.6\%, respectively). Backward simulations showed different patterns for May and July (Fig. 6B). The May simulation advected a large fraction of the particles into the study area from the near coastal area all along the northwestern coast of the Lofoten Islands, in contrast to few particles from the off-shelf area farther south $(5 \%)$. In July, most of the particles originated from the continental shelf adjacent to the release area, with $73.9 \%$ of the particles remaining north of $68^{\circ} \mathrm{N} 4$ wk prior to sampling (compared with $11.9 \%$ in May).

Table 4. Mantel (upper triangle) and partial Mantel statistics (lower triangle) for logarithmic-transformed meroplankton data, environmental data, and space. $p$-values are given in parentheses

\begin{tabular}{|lccc|}
\hline & Meroplankton (log) & Environment & Space \\
\hline Meroplankton (log) & - & $0.159(0.029)$ & $-0.014(0.589)$ \\
Environment & $0.182(0.020)$ & - & $0.426(<0.001)$ \\
Space & $-0.091(0.969)$ & $0.434(<0.001)$ & - \\
\hline
\end{tabular}

\section{DISCUSSION}

Our results showed that diverse planktonic larvae of benthic invertebrates contribute to the planktonic community on the Lofoten-Vesterålen shelf from at least April until September, with maximum abundances during summer. Although we identified 65 taxa in 11 phyla, indicating a considerably higher meroplankton diversity than reported for other northern polar regions (44 taxa in the Kara Sea [Fetzer \& Arntz 2008] and 42 in a north Greenland fjord [Andersen 1984]), this number nonetheless falls short of the diversity reported for temperate waters $(\sim 160$ taxa in the Danish Øresund [Thorson 1946]). We offer 3 possible explanations for this difference in diversity. (1) The meroplankton diversity may directly reflect local benthic diversity, because regional benthic communities ultimately determine meroplankton diversity (Mileikovsky 1968). (2) Following Thorson's rule (Mileikovsky 1971) that postulates fewer planktotrophic species with increasing latitude, meroplankton diversity may reflect the sub-Arctic environment of the Lofoten-Vesterålen region. (3) Differences in sampling protocols and taxonomic resolution may contribute to between-study differences. Presumably, all 3 explanations contribute in some way. The particularly heterogeneous benthic habitats that characterize the Lofoten-Vesterålen region (Buhl-Mortensen et al. 2012) provide niches for a diverse benthic community. Although recent studies refute Thorson's rule for the whole benthic community and instead suggest a shift from planktotrophy to lecitotrophy with increasing latitude, the rule apparently holds for Prosobranchia (Clarke 1992), which were represented by 9 taxa in our present study despite total absence in Kara Sea plankton samples (Fetzer \& Arntz 2008). Furthermore, the higher diversity of bivalves (5 morphotypes in our study vs. 28-33 species in Thorson [1946]) reflects Thorson's taxonomic expertise for molluscs. Additionally, our $200 \mu \mathrm{m}$ mesh size may have underestimated the diversity of bivalve larvae.

Nonetheless, studies of (sub-)Arctic meroplankton from Svalbard and the Barents Sea report the same major components of the meroplankton community as our study. Schlüter \& Rachor (2001), for example, described a community from the central Barents Sea in May and June characterized by echinoderm, polychaete, and Mya truncata larvae. These taxa mirror the meroplankton community in our study on 20 May 2014, but lack abundant barnacles (Semibalanus balanoides, Balanus balanus) 

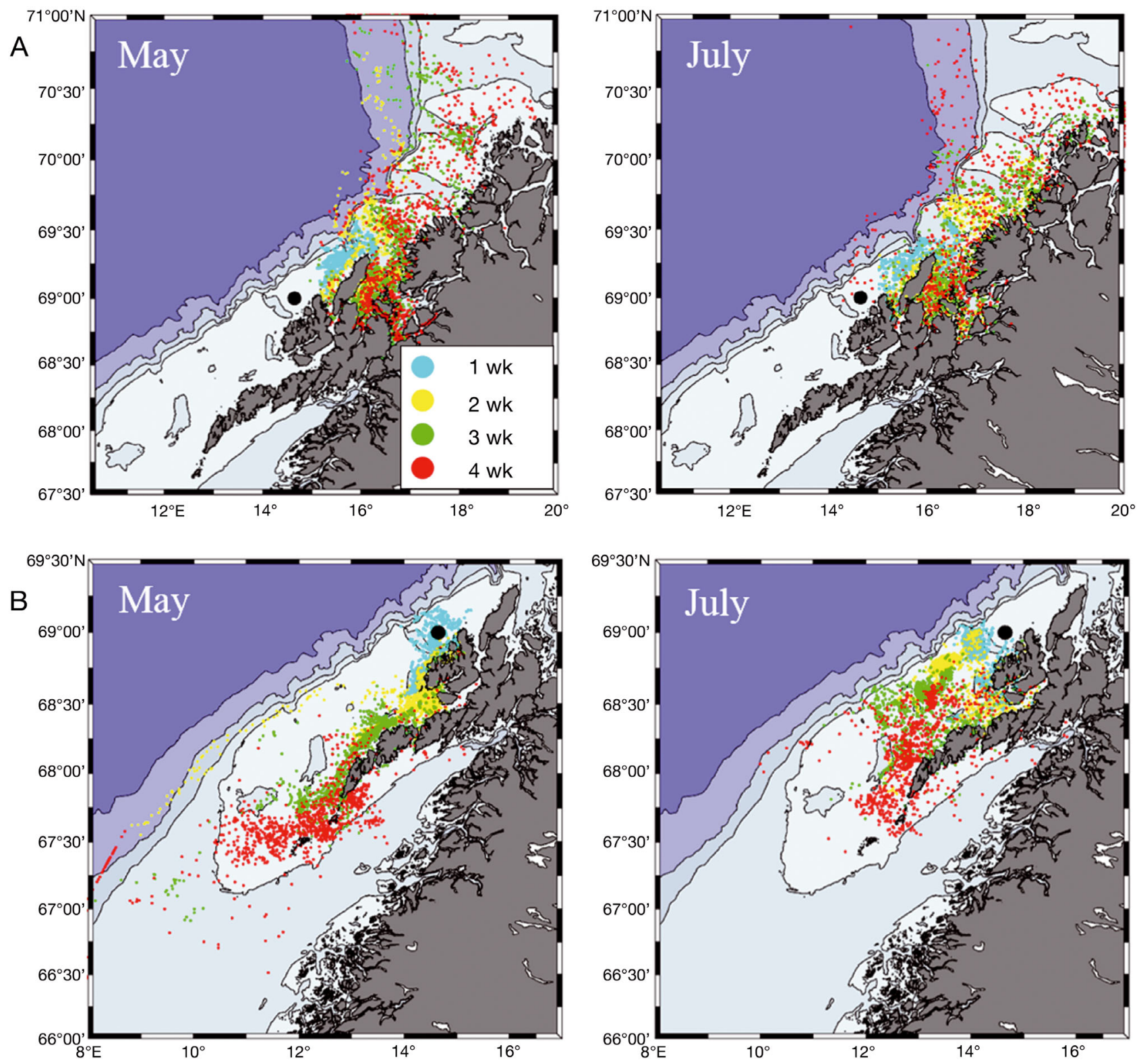

Fig. 6. Particle-tracking results. Forward (A) and backward (B) simulations of larval transport for the meroplankton community on 1 May 2014 (left) and 22 July 2014 (right). Particle distributions are presented in 1 wk steps (see color scale) following (A) or before (B) being observed at the black circle

and bryozoans (Membranipora membranacea, Electra pilosa), typically associated with hard substrates and shallow depth. In contrast, studies from Svalbard fjords reported peak abundances of barnacle larvae in May-June (Willis et al. 2006, Kuklinski et al. 2013, Stübner et al. 2016).

Only Kuklinski et al. (2013) and Stübner et al. (2016) have reported on a meroplankton community over a full annual cycle in an area similar to the LofotenVesterålen region with respect to the physical environment. Like the Lofoten-Vesterålen region, their
Adventfjord study location on Svalbard experiences strong seasonality in day length and a short period of high primary production. In addition, the absence of winter sea-ice, the strong influence of Atlantic water, and increased freshwater input during the melting season in late summer characterize Adventfjord. Species with low-Arctic, boreal-Arctic, Arctic-boreal, and Atlantic biogeographic origin occur commonly in Adventfjord (Różycki 1993). Although the Adventfjord studies (Kuklinski et al. 2013, Stübner et al. 2016) used different sampling schemes to characterize the 
meroplankton community over a 1 yr period, both studies nonetheless identified similar seasonal development, with meroplankton present in larger numbers from mid-April to the end of July. Within this period, they identified a spring community dominated by barnacles and a summer community dominated by molluscs. We report similar spring and summer communities in Lofoten-Vesterålen, characterized by the same groups. Two barnacle species dominated the spring community in contrast to abundant bivalve and gastropod taxa during the summer. The occurrence of other abundant taxa resulted in reduced dominance by the previously mentioned taxa in Lofoten-Vesterålen. Amphinomid polychaetes Verruca stroemia and the 2 bryozoan species occurred in lower numbers in Svalbard. This amphinomid, quite likely Paramphinome jeffreysii, occurs frequently and in high abundances in fjords of mainland Norway and on the continental shelf. No study has reported adults of $P$. jeffreysii in Svalbard. Regarding bryozoans, Stübner et al. (2016) reported a very different seasonal pattern than that in Kuklinski et al. (2013) or in our study. Stübner et al. (2016) observed very few bryozoans and exclusively during winter months, when virtually all other larvae were absent. In contrast, our samples contained high numbers of bryozoans almost throughout the complete spring and summer. Species with different larval types may explain this result (Temkin \& Zimmer 2002). The planktivorous cyphonautes larvae of the species in our study spend a relatively long time in the plankton. Although Stübner et al. (2016) did not mention larval type, they likely observed small lecithotrophic larvae with a short planktonic period that do not require food while in the pelagic zone. Kuklinski et al. (2013) reported a high number of noncyphonautes bryozoans, but also very low numbers of cyphonautes larvae. However, in their study the noncyphonautes larvae appeared in April right after the spring phytoplankton bloom and disappeared from the water again in June.

\section{Spatial and seasonal structure}

Our analysis identified seasonal as well as spatial structure in the environment. However, our results also showed strong seasonal structure in the meroplankton community with little spatial structure other than the spatial patterns described for B. balanus, S. balanoides, Amphinomidae, and Munida spp.

Studies that sample single time periods often report spatial structure in meroplankton communities, frequently relating patterns to observed water mass properties on a regional scale (Belgrano et al. 1995a,b, Ayata et al. 2011) or to differences in marine landscape (coast vs. shelf vs. oceanic) on a larger scale (Koettker \& Lopes 2013). Year-round studies of meroplankton communities (Kuklinski et al. 2013, Weidberg et al. 2013) have not reported such spatial structure, perhaps relating to study design and the highly dynamic nature of pelagic ecosystems. Sampling campaigns for seasonal studies require extensive, repetitive sampling cruises. Therefore, the limited spatial coverage and number of samples make it impossible to detect weak spatial structure. However, the lack of spatial structure in the meroplankton community in our study could well be related to the particularly dynamic pelagic system in the study area (Røed \& Kristensen 2013). A strong cross-shelf mixing in the study area is also in accordance with the particle-tracking results in this study. In each simulation, the particles were evenly distributed over the width of the shelf $1 \mathrm{wk}$ before and after their release.

The strong seasonal changes in meroplankton in our study coincide with past studies of Arctic (Willis et al. 2006, Kuklinski et al. 2013, Stübner et al. 2016) and Antarctic (Stanwell-Smith et al. 1999) waters, as well as studies of temperate waters in Britain (Highfield et al. 2010) and northern Spain (Weidberg et al. 2013). We identified a winter period with very low abundances of meroplankton, as commonly reported in previous Northern Hemisphere temperate ( 2 mo) and Arctic ( 8 mo) studies.

The absence of early and late spawning species, or delayed and advanced spawning of early and late spawning species, respectively, may explain the shortened period of larval presence at high latitudes. The recurring dominance of barnacle larvae in spring characterizes meroplankton communities all along the European coast (Pyefinch 1948, Crisp 1962, Kuklinski et al. 2013, Weidberg et al. 2013). In British waters, early naupli of $S$. balanoides, B. balanus, and $V$. stroemia more or less co-occur in February-March (Pyefinch 1948, Crisp 1962), when the spring phytoplankton bloom triggers larval release (Crisp \& Spencer 1958, Barnes \& Stone 1973). Crisp (1962) showed a similar delay in larval release with increasing latitude for $S$. balanoides and B. balanus. In our study, however, V. stroemia appeared later in the season than the other barnacles. Stone (1989) showed experimentally that $S$. balanoides naupli feed on large diatoms, whereas $V$. stroemia develops better when fed small flagellates. Therefore, although the temporal succession of barnacle species in LofotenVesterålen suggests adaptation to the regional tem- 
poral succession of the phytoplankton community in northern Norway (Tande 1991), the causes for the longer delay in $V$. stroemia remain unclear.

Mytilidae larvae vary seasonally with environmental conditions on spatial scales of $100 \mathrm{~s}-1000 \mathrm{~s}$ of $\mathrm{km}$ (Philippart et al. 2012). Accordingly, Mytilidae abundance in our summer community strongly resembles the pattern in the White Sea (Günther \& Fedyakov 2000), but differs from temperate regions in Europe (Philippart et al. 2012). Such large-scale similarities apparently hold for other bivalve species as seen by similarity in Mya spp. occurrence in Lofoten-Vesterålen and the Barents Sea (Schlüter \& Rachor 2001).

\section{Parental populations and settlement locations}

Our particle-tracking simulation indicated very different origins of spring (coast) and summer (shelf) meroplankton communities, but advection of a large proportion of the larvae into Andfjord in both seasons. Unfortunately, a lack of information on the distributions of adult benthic populations in the LofotenVesterålen region precludes any validation of possible spawning or settlement locations. We assumed particles in our simulations behaved passively without behavior, though previous studies have shown that vertical migration can reduce transport distances and risk of offshore transport (Robins et al. 2013). Therefore, our simulation may overestimate dispersal distances for some taxa, and we assume that the fraction of larvae that settled in Andfjord and adjacent shelf areas may represent underestimates in both seasons. This high local settlement points to the importance of the meroplankton community for the resilience of local benthic assemblages. Furthermore, perhaps even fewer larvae were transported offshore than our simulations suggested. Therefore, we propose a minimal risk of offshore transport for meroplankton in the Lofoten-Vesterålen region, as proposed by Mileikovsky (1968) based on his observation of low larval abundances in Norwegian Sea offshore waters.

Species composition on 1 May 2014 supports a coastal origin for larvae. Given its intertidal distribution, we can easily presume a coastal origin for $S$. balanoides larvae (Hayward \& Ryland 1995). B. balanus occurs on, though is not restricted to, hard substrates in shallow coastal waters. Various brittle stars with ophiopluteus larvae commonly occur in northern Norway (Mortensen 1927), including Ophiopholis aculeata, and several Ophiura species, which are very common on the Lofoten-Vesterålen and Nordland
County coasts (M. J. Silberberger pers. obs.). Similar transport pathways were described for a 2011 early spring simulation (Espinasse et al. 2016). A simulated particle release in Vestfjorden on 15 March 2011 resulted in advection along the Lofoten coast and some particles reaching our study location within $3 \mathrm{wk}$.

Amphinomidae (P. jeffreysii), V. stroemia, and Mytilidae, all abundant taxa in samples from 22 July 2014, support the hypothesis of a dominant shelf origin of the summer community. However, these taxa occur beyond the shelf. P. jeffreysii also commonly occurs in north Norwegian fjords. V. stroemia occurs from the low littoral zone to several hundred meters depth (Stone \& Barnes 1973). Likewise, the common Mytilidae species Modiolus modiolus occurs in northern Norway from a few meters to over $200 \mathrm{~m}$ depth. In contrast, the bryozoans $M$. membranacea and $E$. pilosa commonly associated with kelp and shallow waters originate from shore (Hayward \& Ryland 1995). Although this observation contradicts our hypothesis of the summer community originating on the shelf, our particle-tracking simulation nonetheless showed a fraction of the particles originated from the coast in July as well.

Variability in circulation at small timescales can strongly influence generalizations drawn from the simulations regarding seasonal patterns in larval transport. Especially in the surface layer, changes in wind conditions can significantly alter transport. However, the 2 simulations identify some clear differences in seasonal patterns. Early in the year, prevailing southwest winds push water masses transported by the Norwegian Coastal Current towards the coast, thus strengthening the current. During summer, the prevailing northerly winds decrease Norwegian Coastal Current flow, producing lower advection and shorter transport pathways in summer compared with spring.

We conclude that a distinctly seasonal sub-Arctic meroplankton community, which is considerably more diverse than documented in previous Arctic studies, characterizes the Lofoten-Vesterålen region. Nonetheless, the diversity of meroplankton clearly reflects only a subset of the entire local benthic diversity. Low taxonomic resolution for some meroplankton may partly explain this discrepancy, but it may also indicate a high proportion of benthic organisms with direct development, short planktonic duration, or near-bottom larval distributions, which our sampling campaign did not capture. Our study revealed surprisingly little spatial variation across the continental shelf, despite large-scale differences in benthic habitats at the sampling locations. Particle tracking revealed some interesting transport patterns, 
particularly given that water column properties at our sampling locations did not satisfactorily explain the observed variation in the meroplankton community. The simulated transport pathways indicate that mesoand large-scale oceanographic processes in the study area must be considered when estimating the potential of benthic communities for recovery from disturbances. At the same time, our study demonstrated the need for detailed knowledge of adult distributions and a better understanding of the mechanisms triggering larval release. Furthermore, assessment of the potential impacts of natural and anthropogenic disturbances on the resilience of Arctic and sub-Arctic benthic communities will likely require the use of new molecular methods that offer better taxonomic resolution than morphological approaches.

Acknowledgements. We thank the captains and crews of all vessels involved in the sampling campaign. Special thanks to J. A. Kristensen for energy and enthusiasm for the intensive work at sea and related logistics. Thanks also to K. Gall for her support in the lab and at sea. Thanks to V. Remen, A. S. Aniceto and S. E. Enoksen for their assistance in the field. We thank J. Albretsen (IMR) for providing modeled velocity fields. We thank Paul Snelgrove and 4 reviewers for comments that improved the manuscript. This study is a contribution of the ARCTOS LoVe MarinEco project, made possible through the support of Statoil.

\section{LITERATURE CITED}

Albretsen J, Sperrevik A, Staalstrøm A, Sandvik A, Vikebø F, Asplin L (2011) NorKyst-800 report no. 1: user manual and technical descriptions. Fisken Havet 2/2011

Andersen OGN (1984) Meroplankton in Jørgen Brønlund Fjord, North Greenland. Medd Gronl Biosci 12:1-25

- Anderson M, Cribble N (1998) Partitioning the variation among spatial, temporal and environmental components in a multivariate data set. Aust J Ecol 23:158-167

> Ayata SD, Stolba R, Comtet T, Thiébaut É (2011) Meroplankton distribution and its relationship to coastal mesoscale hydrological structure in the northern Bay of Biscay (NE Atlantic). J Plankton Res 33:1193-1211

> Barnes H, Stone R (1973) The general biology of Verruca stroemia (OF Müller). II. Reproductive cycle, population structure, and factors affecting release of nauplii. J Exp Mar Biol Ecol 12:279-297

> Becker BJ, Levin LA, Fodrie FJ, McMillan PA (2007) Complex larval connectivity patterns among marine invertebrate populations. Proc Natl Acad Sci USA 104:3267-3272

Belgrano A, Legendre P, Dewarumez JM, Frontier S (1995a) Spatial structure and ecological variation of meroplankton on the Belgian-Dutch coast of the North Sea. Mar Ecol Prog Ser 128:51-59

> Belgrano A, Legendre P, Dewarumez JM, Frontier S (1995b) Spatial structure and ecological variation of meroplankton on the French-Belgian coast of the North Sea. Mar Ecol Prog Ser 128:43-50

Bivand R, Rundel C, Pebesma E, Hufthammer KO (2015) rgeos: interface to geometry engine-open source (GEOS). R package version 0.3-11. https://cran.r-project.org/web/ packages/rgeos/index.html

Bøe R, Bellec VK, Dolan MF, Buhl-Mortensen P, BuhlMortensen L, Slagstad D, Rise L (2009) Giant sandwaves in the Hola glacial trough off Vesterålen, North Norway. Mar Geol 267:36-54

$>$ Bray JR, Curtis JT (1957) An ordination of the upland forest communities of southern Wisconsin. Ecol Monogr 27: 325-349

Buhl-Mortensen L, Buhl-Mortensen P, Dolan M, Dannheim J, Bellec V, Holte B (2012) Habitat complexity and bottom fauna composition at different scales on the continental shelf and slope of northern Norway. Hydrobiologia 685:191-219

Clarke A (1992) Reproduction in the cold: Thorson revisited. Invertebr Reprod Dev 22:175-183

> Clough L, Ambrose W Jr, Ashjian C, Piepenburg D, Renaud P, Smith S (1997) Meroplankton abundance in the Northeast Water Polynya: insights from oceanographic parameters and benthic abundance patterns. J Mar Syst 10: 343-357

Conway D (2015) Marine zooplankton of southern Britain. Part 3: Ostracoda, Stomatopoda, Nebaliacea, Mysida, Amphipoda, Isopoda, Cumacea, Euphausiacea, Decapoda, Annelida, Tardigrada, Nematoda, Phoronida, Bryozoa, Entoprocta, Brachiopoda, Echinodermata, Chaetognatha, Hemichordata and Chordata. Occasional Publications Marine Biological Association of the United Kingdom no. 27. Marine Biological Association, Plymouth

Crisp D (1962) The planktonic stages of the Cirripedia Balanus balanoides (L.) and Balanus balanus (L.) from north temperate waters. Crustaceana 3:207-221

Crisp D, Spencer C (1958) The control of the hatching process in barnacles. Proc R Soc B 149:278-299

Daase M, Falk-Petersen S, Varpe Ø, Darnis G and others (2013) Timing of reproductive events in the marine copepod Calanus glacialis: a pan-Arctic perspective. Can J Fish Aquat Sci 70:871-884

> Espinasse B, Basedow SL, Tverberg V, Hattermann T, Eiane K (2016) A major Calanus finmarchicus overwintering population inside a deep fjord in northern Norway: implications for cod larvae recruitment success. J Plankton Res 38:604-609

Fetzer I, Arntz WE (2008) Reproductive strategies of benthic invertebrates in the Kara Sea (Russian Arctic): adaptation of reproduction modes to cold water. Mar Ecol Prog Ser 356:189-202

Gauch Jr. HG (1973) A quantitative evaluation of the BrayCurtis ordination. Ecology 54:829-836

Günther CP, Fedyakov VV (2000) Seasonal changes in the bivalve larval plankton of the White Sea. Senckenb Marit 30:141-151

Hadfield M, Strathmann M (1996) Variability, flexibility and plasticity in life histories of marine invertebrates. Oceanol Acta 19:323-334

> Haidvogel D, Arango H, Budgell W, Cornuelle B and others (2008) Ocean forecasting in terrain-following coordinates: formulation and skill assessment of the Regional Ocean Modeling System. J Comput Phys 227:3595-3624

Hayward PJ, Ryland JS (1995) Handbook of the marine fauna of North-West Europe. Oxford University Press, Oxford

Highfield JM, Eloire D, Conway DV, Lindeque PK, Attrill MJ, 
Somerfield PJ (2010) Seasonal dynamics of meroplankton assemblages at station L4. J Plankton Res 32:681-691

IOC, SCOR, IAPSO (Intergovernmental Oceanographic Commission, Scientific Committee on Oceanic Research, International Association for the Physical Sciences of the Oceans) (2010) The international thermodynamic equation of seawater - 2010: calculation and use of thermodynamic properties. Intergovernmental Oceanographic Commission, Manuals and Guides No. 56. UNESCO, Paris

Johannesson K (1988) The paradox of Rockall: Why is a brooding gastropod (Littorina saxatilis) more widespread than one having a planktonic larval dispersal stage $(L$. littorea)? Mar Biol 99:507-513

Kelley D, Richards C, WG127 SCOR/IAPSO (2015) gsw: Gibbs SeaWater Functions. R package version 1.0-3. https://cran.r-project.org/web/packages/gsw/index.html

Kirby RR, Beaugrand G, Lindley JA (2008) Climate-induced effects on the meroplankton and the benthic-pelagic ecology of the North Sea. Limnol Oceanogr 53:1805-1815

Koettker AG, Lopes RM (2013) Meroplankton spatial structure and variability on Abrolhos Bank and adjacent areas, with emphasis on brachyuran larvae. Cont Shelf Res 70:97-108

Kuklinski P, Berge J, McFadden L, Dmoch K and others (2013) Seasonality of occurrence and recruitment of Arctic marine benthic invertebrate larvae in relation to environmental variables. Polar Biol 36:549-560

Legendre P (1990) Quantitative methods and biogeographic analysis. In: Garbary DJ, South GR (eds) Evolutionary biogeography of the marine algae of the North Atlantic. Springer, Berlin, p 9-34

Legendre P, Legendre L (1998) Numerical ecology, 2nd edn. Developments in environmental modelling, Vol 20. Elsevier Science B.V., Amsterdam

Lett C, Verley P, Mullon C, Parada C, Brochier T, Penven P, Blanke B (2008) A Lagrangian tool for modelling ichthyoplankton dynamics. Environ Model Softw 23:1210-1214

Metaxas A (2001) Behaviour in flow: perspectives on the distribution and dispersion of meroplanktonic larvae in the water column. Can J Fish Aquat Sci 58:86-98

Micallef L, Rodgers P (2014) euler APE: drawing area-proportional 3-venn diagrams using ellipses. PLOS ONE 9:e101717

Mileikovsky S (1968) Distribution of pelagic larvae of bottom invertebrates of the Norwegian and Barents Seas. Mar Biol 1:161-167

Mileikovsky S (1971) Types of larval development in marine bottom invertebrates, their distribution and ecological significance: a re-evaluation. Mar Biol 10:193-213

Mortensen T (1927) Handbook of the echinoderms of the British Isles. Oxford University Press, Edinburgh

Mortensen PB, Buhl-Mortensen L, Dolan M, Dannheim J, Kröger K (2009) Megafaunal diversity associated with marine landscapes of northern Norway: a preliminary assessment. Nor J Geol 89:163-171

Myksvoll MS, Jung KM, Albretsen J, Sundby S (2014) Modelling dispersal of eggs and quantifying connectivity among Norwegian coastal cod subpopulations. ICES J Mar Sci 71:957-969

NGA (National Geospatial-Intelligence Agency) (2009) Global shoreline data white paper. National GeospatialIntelligence Agency, Springfield, VA

O'Connor MI, Bruno JF, Gaines SD, Halpern BS, Lester SE,
Kinlan BP, Weiss JM (2007) Temperature control of larval dispersal and the implications for marine ecology, evolution, and conservation. Proc Natl Acad Sci USA 104: 1266-1271

> Oksanen J, Blanchet FG, Kindt R, Legendre P and others (2015) vegan: community ecology package. R package version 2.3-0. https://cran.r-project.org/web/packages/ vegan/index.html

Palumbi SR (2003) Population genetics, demographic connectivity, and the design of marine reserves. Ecol Appl 13:146-158

Pechenik JA (1999) On the advantages and disadvantages of larval stages in benthic marine invertebrate life cycles. Mar Ecol Prog Ser 177:269-297

Philippart CJ, Amaral A, Asmus R, van Bleijswijk J and others (2012) Spatial synchronies in the seasonal occurrence of larvae of oysters (Crassostrea gigas) and mussels (Mytilus edulis/galloprovincialis) in European coastal waters. Estuar Coast Shelf Sci 108:52-63

Pielou EC (1977) Mathematical ecology. Wiley, New York, NY

Pyefinch K (1948) Notes on the biology of cirripedes. J Mar Biol Assoc UK 27:464-503

R Core Team (2015) R: a language and environment for statistical computing. R Foundation for Statistical Computing, Vienna

$>$ Renaud PE, Sejr MK, Bluhm BA, Sirenko B, Ellingsen IH (2015) The future of Arctic benthos: expansion, invasion, and biodiversity. Prog Oceanogr 139:244-257

- Robins PE, Neill SP, Giménez L, Jenkins SR, Malham SK (2013) Physical and biological controls on larval dispersal and connectivity in a highly energetic shelf sea. Limnol Oceanogr 58:505-524

Røed LP, Kristensen NM (2013) BaSIC technical report no. 1: the triply nested model system. met.no report $1 / 2013$, Norwegian Meteorological Institute, Oslo

Różycki O (1993) Shallow-water molluscs of Isfjorden (West Spitsbergen, Svalbard). Pol Polar Res 14:55-64

Schlüter M, Rachor E (2001) Meroplankton distribution in the central Barents Sea in relation to local oceanographic patterns. Polar Biol 24:582-592

Shanks AL, Grantham BA, Carr MH (2003) Propagule dispersal distance and the size and spacing of marine reserves. Ecol Appl 13:159-169

Shannon CE (1948) A mathematical theory of communication. Bell Syst Tech J 27:379-423, 623-656

Shchepetkin AF, McWilliams JC (2005) The regional oceanic modeling system (ROMS): a split-explicit, free-surface, topography-following-coordinate oceanic model. Ocean Model 9:347-404

Skarðhamar J, Skagseth Ø, Albretsen J (2015) Diurnal tides on the Barents Sea continental slope. Deep-Sea Res I 97: $40-51$

Stanwell-Smith D, Peck LS, Clarke A, Murray AW, Todd CD (1999) The distribution, abundance and seasonality of pelagic marine invertebrate larvae in the maritime Antarctic. Philos Trans R Soc Lond B Biol Sci 354: 471-484

Stone CJ (1989) A comparison of algal diets for cirripede nauplii. J Exp Mar Biol Ecol 132:17-40

Stone R, Barnes H (1973) The general biology of Verruca stroemia (OF Müller). I. Geographical and regional distribution; cirral activity and feeding. J Exp Mar Biol Ecol 12:167-185 
Stübner E, Søreide J, Reigstad M, Marquardt M, Blachowiak-Samolyk K (2016) Year-round meroplankton dynamics in high-Arctic Svalbard. J Plankton Res 38: 522-536

Talley LD, Pickard GL, Emery WJ, Swift JH (2011) Descriptive physical oceanography: an introduction. Academic Press, San Diego, CA

Tande KS (1991) Calanus in North Norwegian fjords and in the Barents Sea. Polar Res 10:389-408

Temkin MH, Zimmer RL (2002) Phylum Bryozoa. In: Young CM, Sewell MA, Rice ME (eds) Atlas of marine invertebrate larvae. Academic Press, San Diego, CA

Thorson G (1946) Reproduction and larval development of Danish marine bottom invertebrates, with special reference to the planktonic larvae in the sound (Oresund). Meddelelser fra Kommissionen for Danmarks Fiskeri- og Havundersøkelser Serie. Plankton 4:1-523

Editorial responsibility: Paul Snelgrove, St. John's, Newfoundland and Labrador, Canada
Thorson G (1950) Reproductive and larval ecology of marine bottom invertebrates. Biol Rev Camb Philos Soc 25: $1-45$

van Son TC, Halvorsen R (2014) Multiple parallel ordinations: the importance of choice of ordination method and weighting of species abundance data. Sommerfeltia 37 : $1-37$

Varpe Ø, Jørgensen C, Tarling GA, Fiksen $\varnothing$ (2009) The adaptive value of energy storage and capital breeding in seasonal environments. Oikos 118:363-370

Weidberg N, Acuña JL, Lobón C (2013) Seasonality and fine-scale meroplankton distribution off the central Cantabrian Coast. J Exp Mar Biol Ecol 442:47-57

Willis K, Cottier F, Kwasniewski S, Wold A, Falk-Petersen S (2006) The influence of advection on zooplankton community composition in an Arctic fjord (Kongsfjorden, Svalbard). J Mar Syst 61:39-54

Submitted: December 28, 2015; Accepted: June 23, 2016

Proofs received from author(s): August 10, 2016 